\title{
Construction technology for affordable housing with the use of space-braced concrete-filled steel tubular framing
}

\author{
Mykola Savytskyi ${ }^{1}$, Tetiana Nikiforova $^{1}$, Oleh Nosenko $^{1}$, Mykola Kotov $^{1}$, and Ruslan Papirnyk ${ }^{1}$ \\ ${ }^{1}$ Prydniprovska State Academy of Civil Engineering and Architecture, Department of Reinforced Concrete and Masonry Structures, \\ 24-A, Chernyshevskoho Str., Dnipro, 49000, Ukraine
}

\begin{abstract}
Among many tasks to be done by the state, the most significant is a social-economic one i.e. provision of its citizens with affordable, long-lasting, energy- efficient and economical housing. One of the ways of doing the given task is the application of concrete-filled steel tubular (CFST) structures, for the elements of a building, of circular, square or rectangular type. It is also possible to use such structures not only for a new housing stock but in the reconstruction of present one at the expense of additional storeys (about 20); without demolition and total resettlement of tenants of the house under reconstruction. Alongside with this, there is an opportunity to increase total area of residential houses and make new types of comfortable place of various purpose.
\end{abstract}

\section{Introduction}

At present buildings from monolithic reinforced concrete in shallow and large-panel formwork are erected using large-block and frame construction technology. Volume of brick, panel and frame-panel house construction has declined strongly. Expansion of monolithic-framing house construction causes considerable capital investments connected with frameworks, depends on weather conditions, it is characterized by big material consumption and accordingly construction cost and terms.

In foreign construction practice the most widely used are not bearing monolithic building envelopes or reinforced concrete columns but as well as combined frame-core system with a bearing core made of monolithic reinforced concrete and external frame made as a bearing shape of columns peripherally located to a building, which is rationally combined with horizontal outrigger-foundation frame work located in every 15-25 storeys [1-4].

In Australia the first residential building (46 storeys) was built in 1990 in Melbourne. The core of the building was formed with steel concrete shafts. 24 CFST columns were located peripherally the building. In Japan 57storey building was built with the use of concrete-filled steel tubes. The base of the building is a CFST framing. Concrete-filled steel tubes are widely used in China in the last decades. A large number of skyscrapers were built in China using CFST frames.

In practice of industrial construction in Ukraine CFST structures are used limitedly until now; there are single examples of the use of CFST columns in residential construction that proved their technological efficiency [5-7].

Concrete-filled steel tubes possess extremely high bearing ability herewith having significantly less cross section of a column. It is the bright example of complex materials that combines optimally strong sides of concrete and metal. Metallic shape functions as a permanent formwork in a CFST column and after concreting process, it reinforces the column either in cross or longitudinal direction that allows to meet any loads applied at any angles. Concrete in such a column is in an optimal state for itself, all-around compression and in such a condition, it withstands loads significantly exceeding its prism strength [1]. The fact is that CFST structures differ in their ability to withstand large loads for a long time in extreme conditions for high-rise and large-span buildings; unlike with steel and reinforced concrete structures losing their bearing ability immediately.

Concrete-filled steel tubes have also their constructive disadvantages. Because of differential Poisson ratios $(v \mathrm{~s}=0.3 ; v b \approx 0.2)$, one of the main problems is occurrence of significant enough tensile stresses on the border of concrete core and metallic shape. Such stresses as well as concrete setting can lead to the separation of concrete core from mantle pipe during operation process. When concrete separates, durability of an item is reducing and bearing ability as well in a certain level.

Taking into account such single buildings having been erected before, there was elaborated advanced construction technology using steel concrete framing $[10 ; 11]$, herewith we have an opportunity to reduce steel and concrete consumption as well as we can simplify the structure of braced steel concrete frame of a multistoreyed building at the expense of the reduction of labour consumption and construction cost.

Technology improvement is provided with mutually perpendicularly located supporting columns and spandrel beams as well as their junction on flooring level; joints are pin connected and frame itself is provided with 
supporting systems as bracings, joint is pin connected between columns and spandrel beams. Making a frame as a steel concrete one with bracings that are fitted in every span and every storey by the height of a building, includes simultaneously the operation of vertical and horizontal stresses, all elements of framing - columns, spandrel beams, and bracings. Using concrete instead of steel in compression and its filling in compressed elements of a structure causes increasing of local strength of walls, resistance of local failure of thin-wall steel structures in assembling not only in columns and spandrel beams but in joints allowing to reduce total steel consumption.

Bracings are simultaneously interior supports for spandrel beams, that turns them into three-span whole beam, at the expense of that the value of bending moment reduces in spandrel beams and allows significantly (by $1.5 \ldots 2$ times) to reduce their height as well as spans of spandrel beams and columns grid. Pin-connected joint of spandrel beams allows with columns to unify the structure of spandrel beams and bracings, as strains in spandrel beams and bracings slightly differ by dimension independently on their location by the height of a building [3]. The essence of the base of technology is presented on Fig.1. Fig. 2 illustrates the erection stages and the plan of a typical storey. a)

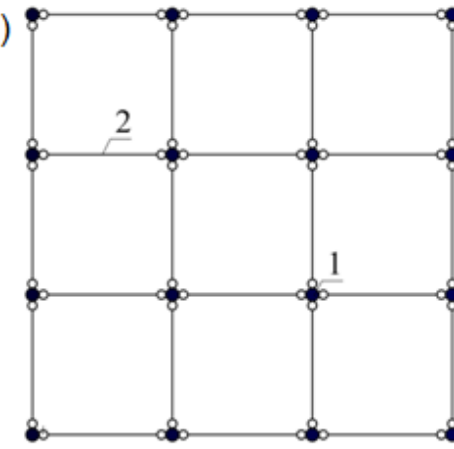

b)

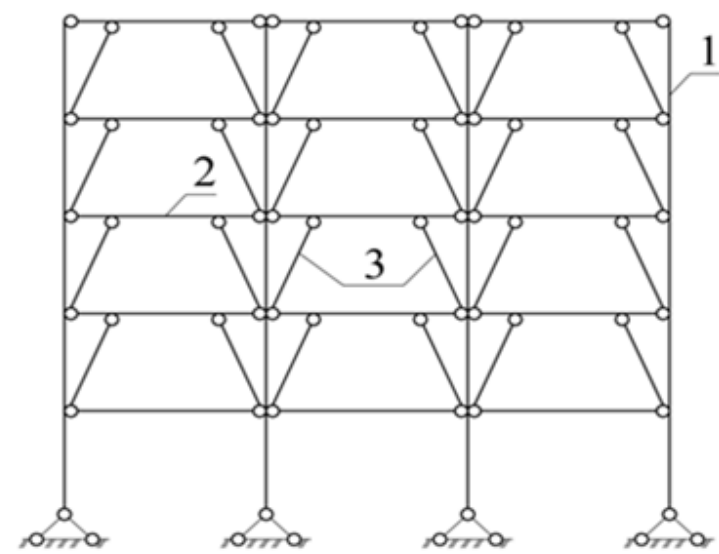

Fig. 1. a) cross section of bracing steel concrete frame; b) longitudinal section of bracing steel concrete frame; c) cross sections of a column and spandrel beams. Where: $1-$ CFST column; 2 - spandrel beam; 3 - bracings.

Framing consists of steel concrete columns (1), steel concrete spandrel beams (2) pin-connected with columns and bracings (3), pin-connected with columns and spandrel beams. Therefore, the essential advantage of such a bracing steel concrete framing with bracings is a significant reduction of construction cost.

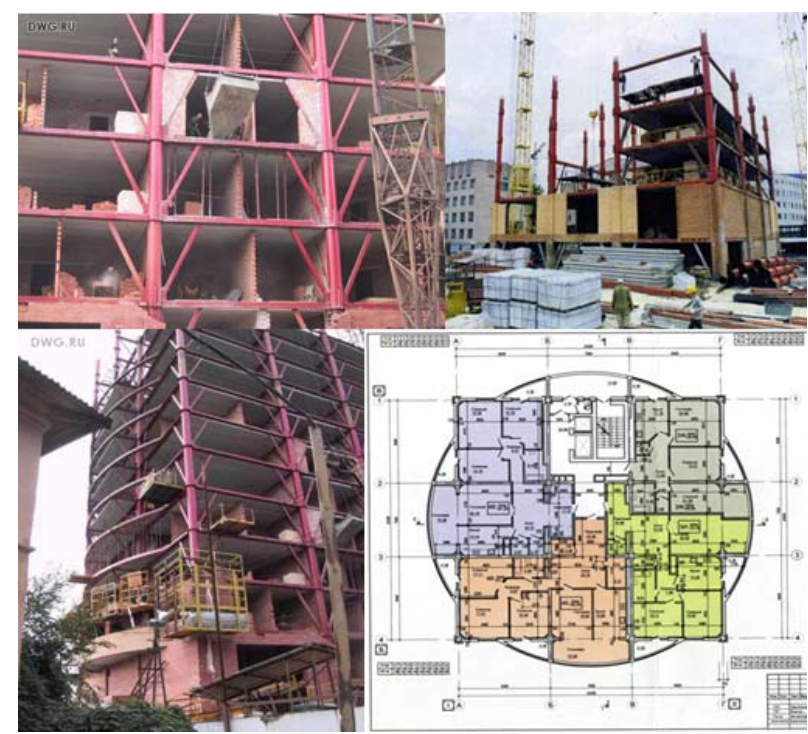

Fig. 2. Erection of buildings with CFST framing in various construction stages.

Reconstruction of residential buildings demands special attention to choose engineering solutions in the improvement of volume-constructive solutions and provision of operating factors with the demands of present regulations $[8 ; 9 ; 10]$.

According to the present constructive solutions, there are three types of a superstructure (Fig. 3):

a) General, without strengthening a present building, superstructure is a high extension of a building saving its constructive scheme; it allows 2-3 additional storeys;

b) Changing its constructive scheme. The given method suggests redistribution of load transmission scheme from the weight of additional storeys and existing building on bearing members loading them equally allowing additional 4-5 storeys.

c) Superstructure plant that is not connected with bearing structures of the present building and supports on individual structures. Such a superstructure can be erected over any building. Essentially, with additional storeys their stress is given to reinforced concrete slab located on columns which are located uniformly by the perimeter of a building and support on their own foundations allowing to add 10-20 storeys. Fig. 1 shows the considered variant of additional storeys. More often similar superstructures are made of reinforced concrete or metallic structures, however, in comparison with metal structures with the same bearing ability, metal consumption reduces twice on average for CFST members but comparing with reinforced concrete ones section of shotcrete members and concrete consumption reduce twice.

In a technological way a steel pipe plays a role of a formwork that significantly simplifies work operations but constructively it plays a role of a case and longitudinal rigid reinforcement. Simple production technology, high construction velocity in the erection of 
monolithic buildings, essential metal economy at the expense of increased bearing ability and significant fire resistance make the structures made of steel pipes filled in with concrete more attractive. Researches show much higher strength of columns in comparison with traditional reinforced concrete ones; it is determined by concrete operation in the condition of triaxial compression. [12$16]$.

a)

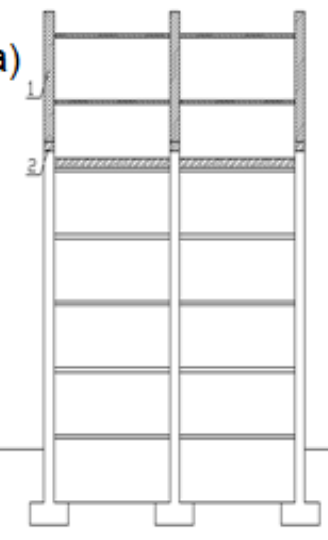

b)

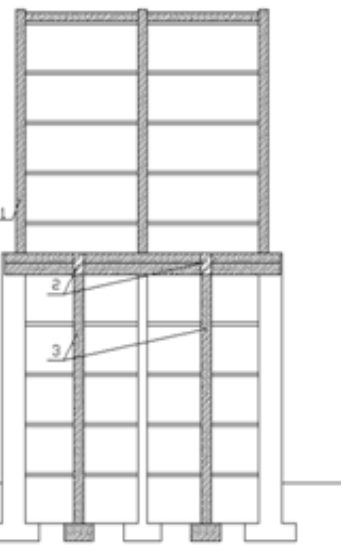

c)
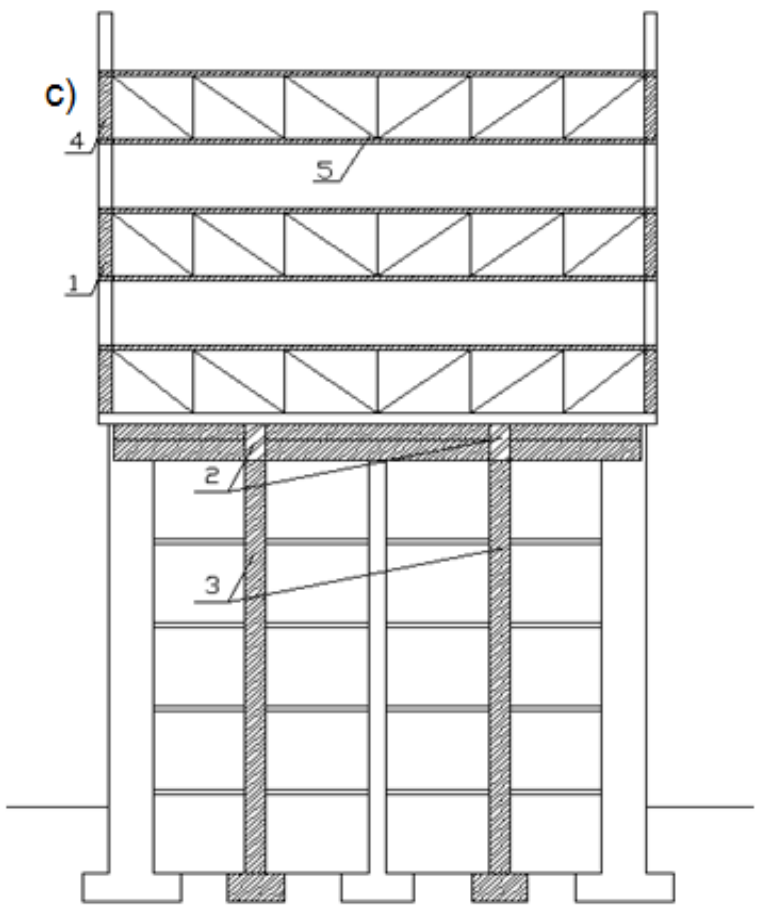

Fig. 3. a) Scheme of an ordinary superstructure: 1 - additional storeys; 2 - stiffening ring. b) Scheme of the superstructure with a changing constructive scheme: 1 - superstructure; 2 main beams of a monolithic platform; 3 - columns. c) Scheme of the superstructure supporting on separate structures: 1 additional storeys; 2 - main beams of a monolithic platform; 3 - columns; 4 - walls of additional storeys; 5 - metallic bearing girders.

\section{Methods}

As concrete-filled steel tubes are a complex material, there are some difficulties in calculation complex. With this purpose we used the methods of unit stiffness, herewith section of a shotcrete member carried into an equivalent section of concrete with a diameter by the formula:

$$
\mathrm{D}_{\text {red }}=\sqrt[4]{\mathrm{D}^{4}+8 \alpha \delta \mathrm{D}_{\mathrm{s}}^{3}}
$$

where: $\alpha$ - ratio of inertia and concrete modulus of elasticity and outer metallic shape;

$\mathrm{D}_{\mathrm{s}}$ - outer diameter of steel shape;

$\mathrm{D}_{\mathrm{b}}$ - outer diameter of concrete;

$\mathrm{D}_{\text {red }}$ - outer given diameter of section.

According to the given method in calculation the presented value of concrete section increases by $2-5 \mathrm{~cm}$ depending on concrete grade, steel grade and thickness of a tube wall. Results are given in Table 1 [16].

Table 1 Presented section of CFST members.

\begin{tabular}{|c|c|c|c|c|}
\hline $\begin{array}{c}\text { Outer } \\
\text { diameter } \\
\text { of a pipe, } \\
\text { cm }\end{array}$ & $\begin{array}{c}\text { Thickness } \\
\text { of a pipe } \\
\text { wall, } \\
\delta \mathrm{cm}\end{array}$ & $\begin{array}{l}\text { Concrete } \\
\text { grade, } B\end{array}$ & $\begin{array}{c}\text { Outer } \\
\text { presented } \\
\text { diameter of } \\
\text { outer } \\
\text { presented } \\
\text { section, Dred, } \\
\text { cm } \\
\end{array}$ & $\begin{array}{c}\text { Modular } \\
\text { ratio, } \alpha\end{array}$ \\
\hline \multirow[t]{5}{*}{42.6} & \multirow[t]{5}{*}{0.5} & $\mathrm{~B} 20$ & 47 & 0.8 \\
\hline & & B30 & 45 & 0.6 \\
\hline & & B40 & 44 & 0.6 \\
\hline & & B50 & 44 & 0.5 \\
\hline & & B60 & 44 & 0.5 \\
\hline \multirow[t]{5}{*}{53.0} & \multirow[t]{5}{*}{0.5} & $\mathrm{~B} 20$ & 56 & 0.6 \\
\hline & & $\mathrm{B} 30$ & 55 & 0.5 \\
\hline & & B40 & 54 & 0.5 \\
\hline & & B50 & 54 & 0.4 \\
\hline & & B60 & 54 & 0.4 \\
\hline
\end{tabular}

\section{Results and discussion}

As the possible variant of using steel reinforced concrete structures in mass civil construction of a new housing or the reconstruction of an old one, there was elaborated the structure of a superstructure of five-storey residential building ('Khrushchev-era house') with the aim of its redevelopment, its frame consists of CFST members.

The structure of a superstructure represents itself as a stack-frame with vertical bearing members, it is twomember columns connected between each other with Пshaped multi-layered frames by girder system, beams and bracings of shaped pipes of square and rectangular section filled in with concrete that ensure space stiffness of a building in cross and longitudinal directions. Step of portal frames was 6.3 and $8.4 \mathrm{~m}$ and associated with the location of partition walls in the present building (Fig. 4).

Loads on the present frame members were taken according to the present regulations. Joint between constructive members of the scheme is presented as pinconnected; eccentricity of load transmission from a girder to columns was considered in calculation as well. Strains occurring in the design model are given in Table 2.

According to DSTU (National Standards of Ukraine) I.1.2.-3:2006 «Bendings and motions» (v.4, p.1) regulations limited horizontal motion of multi-storeyed building should be at most $\mathrm{h} / 500$, i.e. $-100 \mathrm{~mm}$. 
according to the calculation results, minimum bending occurring in a superstructure does not exceed $34 \mathrm{~mm}$.

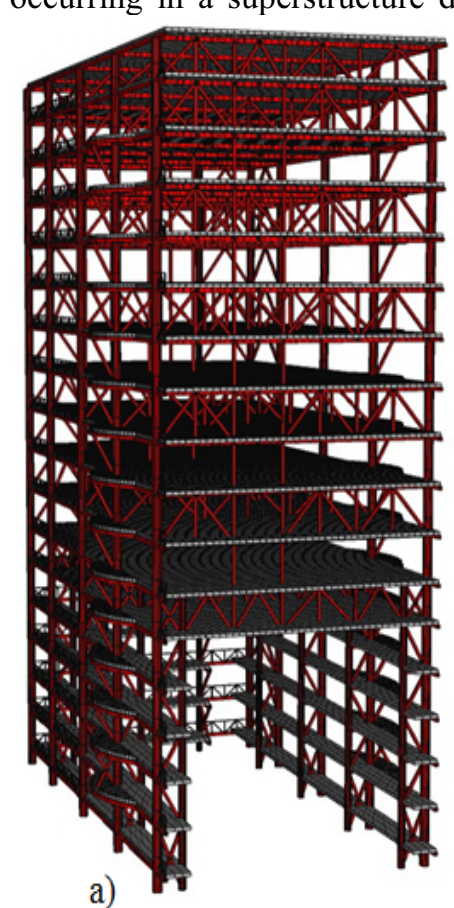

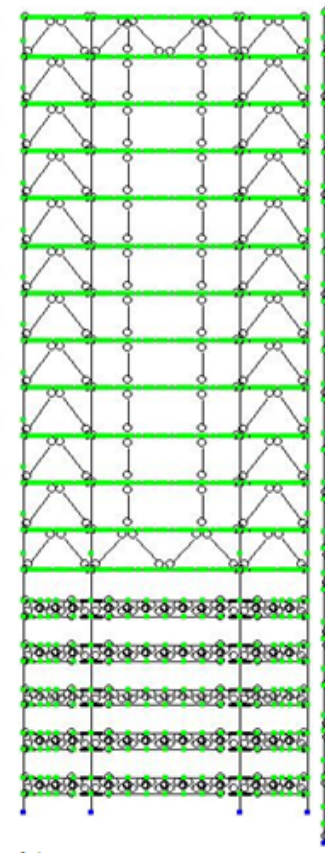

b)

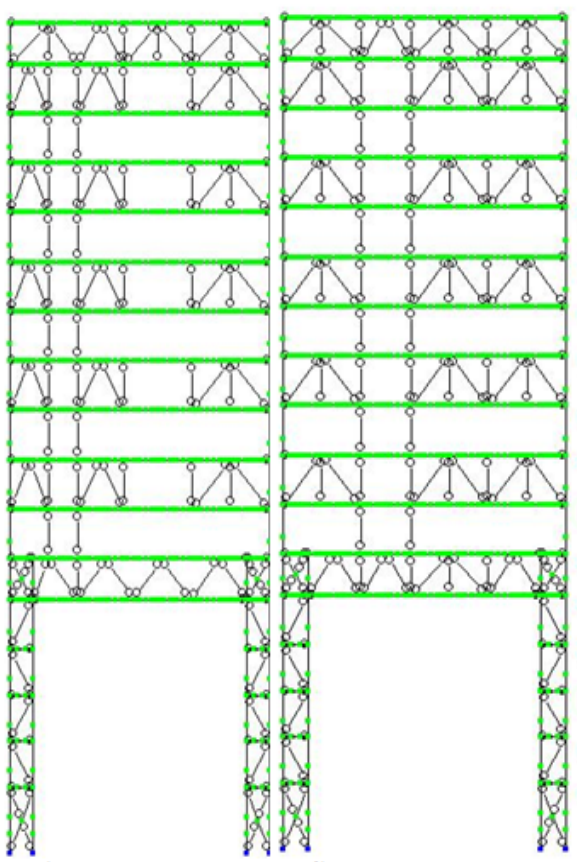

d)

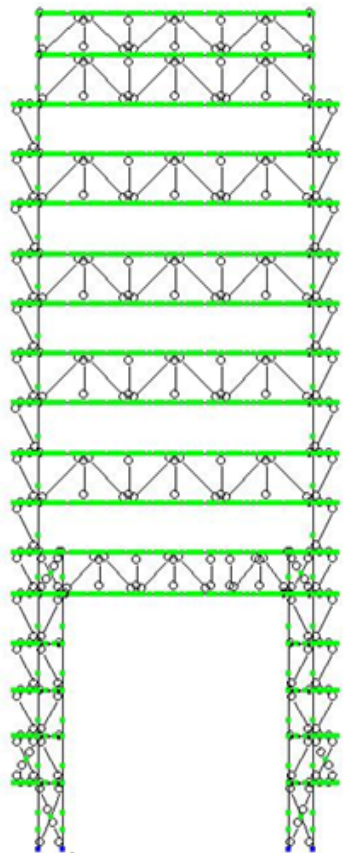

e)

Fig. 4. General design model; b, c, d, e). Various cross-sections of a superstructure.

Table 2. Strains acting in the design model.

\begin{tabular}{|c|c|}
\hline \multicolumn{2}{|c|}{ Maximum strains in an outer part of column } \\
\hline \multicolumn{2}{|c|}{ Variant «a» } \\
\hline Compressive force & $\mathrm{N}=-8950 \mathrm{kN}$ \\
\hline \multirow{2}{*}{ Bending moment } & $\mathrm{M}_{\mathrm{y}}=803 \mathrm{kNm}$ \\
\hline & $\mathrm{Mz}=58 \mathrm{kNm}$ \\
\hline \multicolumn{2}{|c|}{ Maximum strains in an internal of column } \\
\hline \multicolumn{2}{|c|}{ Variant «a» } \\
\hline Compressive force & $\mathrm{N}=-4285 \mathrm{kN}$ \\
\hline \multirow{2}{*}{ Bending moment } & $\mathrm{My}=89 \mathrm{kNm}$ \\
\hline & $\mathrm{Mz}=19 \mathrm{kN}$ \\
\hline \multicolumn{2}{|c|}{ Maximum strains in chords } \\
\hline \multicolumn{2}{|c|}{ Variant «a» } \\
\hline Compressive force & $\mathrm{N}=-530 \mathrm{kN}$ \\
\hline Bending moment & $\mathrm{M}_{\mathrm{y}}=156 \mathrm{kN}$ \\
\hline \multicolumn{2}{|c|}{ Maximum motions } \\
\hline \multicolumn{2}{|r|}{ Variant «a» } \\
\hline Axis motion & $X=30.5 \mathrm{~mm}, Y=11 \mathrm{~mm}, \mathrm{Z}=50 \mathrm{~mm}$ \\
\hline \multicolumn{2}{|c|}{ Maximum strains in an outer part of column } \\
\hline \multicolumn{2}{|c|}{ Variant $« \mathrm{~b} »$} \\
\hline Compressive force & $\mathrm{N}=-9570 \mathrm{kN}$ \\
\hline \multirow{2}{*}{ Bending moment } & $\mathrm{M}_{\mathrm{y}}=1289 \mathrm{kNm}$ \\
\hline & $\mathrm{M}_{\mathrm{z}}=62 \mathrm{kNm}$ \\
\hline \multicolumn{2}{|c|}{ Maximum strains in an internal of column } \\
\hline \multicolumn{2}{|c|}{ Variant «b»» } \\
\hline Compressive force & $\mathrm{N}=-1440 \mathrm{kN}$ \\
\hline \multirow{2}{*}{ Bending moment } & $\mathrm{M}_{\mathrm{y}}=24 \mathrm{kNm}$ \\
\hline & $\mathrm{M}_{\mathrm{z}}=187 \mathrm{kNm}$ \\
\hline \multicolumn{2}{|c|}{ Maximum strains in chords } \\
\hline \multicolumn{2}{|c|}{ Variant $« b » »$} \\
\hline Compressive force & $\mathrm{N}=-1440 \mathrm{kN}$ \\
\hline Bending moment & $\mathrm{M}_{\mathrm{y}}=34 \mathrm{kNm}$ \\
\hline \multicolumn{2}{|c|}{ Maximum motions } \\
\hline \multicolumn{2}{|r|}{ Variant «b» } \\
\hline Axis motion & $\mathrm{X}=30.5 \mathrm{~mm}, \mathrm{Y}=11 \mathrm{~mm}, \mathrm{Z}=50 \mathrm{~mm}$ \\
\hline
\end{tabular}
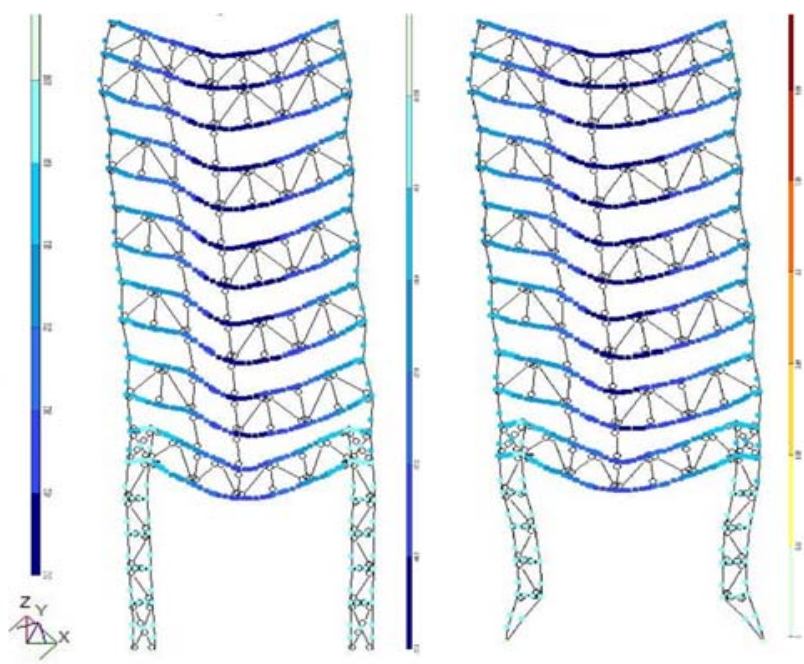

Fig. 5. Mosaic of motions of members a) column with two supporting points on a foundation; $b$ ) column with one supporting point on a foundation.

From designing experience and obtained results, it is known that shotcrete framing with flooring of hollow slabs allows to reduce cost of a frame $20-30 \%$ and shorten construction terms twice. Table 3 demonstrates the parameters of the used CFST frame members.

Flooring is made of pre-fabricated hollow slabs with connectors on lateral areas. Connectors taking main closing strains occurring during the operation of a stiff floor in covering can become monolithic. Provision of strain transfer between members and redistribution of locally applied stresses on neighbouring slabs excludes 'key' effect proper for flooring structures of prefabricated slabs without connectors on a lateral surface (Fig. 6). 
Table 3 Section parameters of the members of CFST framing.

\begin{tabular}{|c|c|c|c|c|c|}
\hline \multirow{2}{*}{$\begin{array}{c}\text { Column } \\
\text { members }\end{array}$} & \multirow{2}{*}{ Sketch } & \multirow{2}{*}{ Sections, mm } & \multicolumn{2}{|c|}{ Supporting strains } & \multirow{2}{*}{ Steel grade } \\
\hline & & & $\mathbf{M} \mathbf{k H} \times \mathbf{m}$ & N kH & \\
\hline Section "b, c", & & Pipes $630 \times 10$ & From 234 to 288 & From -890 to -5223 & St3ps \\
\hline Section "e" & & Pipes $630 \times 10$ & From 586 to -753 & From -1390 до -8840 & St3ps \\
\hline Section "d" & & Pipes $630 \times 10$ & From 586 to 994 & From -796 to 8940 & St3ps \\
\hline \multirow{3}{*}{$\begin{array}{l}\text { Girder members } \\
\text { in all sections }\end{array}$} & & $200 \times 200 \times 6$ & - & From -343 to -1680 & St3ps \\
\hline & & $180 \times 180 \times 6$ & - & From -157 to -7776 & St3ps \\
\hline & & $100 \times 200 \times 11$ & From -51.3 to 47.5 & From -1036 to 1010 & St3ps \\
\hline
\end{tabular}

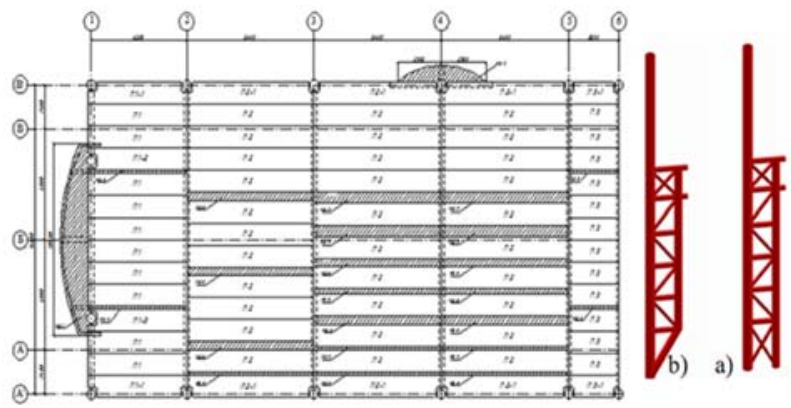

Fig. 6. Monolithic scheme of slabs (7-17 storeys) and two types of columns.

Statistically the floor is the only system where flooring slabs support on spandrel beams of framing and jointed at the expense of longitudinal linear pins. Only cross and longitudinal strains can be transferred through these pins. To make proper stiffness it is necessary to make monolithic stitches and connectors in floorings in vertical and horizontal directions. To reduce bendings it is necessary to make all the flooring members prestressed, herewith the possibility of uneven failures reduces significantly and thus conditions of cooperated work of floorings in slabs can improve. Flooring members acquire the ability to work with shear after hardening of mortar in all stitches.

Calculation of strains and section selection in the scheme elements were made in DK LIRA 9.6 R7. Two variants of a design model were considered (Fig. 9.): twomember lattice column with two supporting points on a foundation (a); lattice column with one supporting point on a foundation (b);

Having obtained strains in the complex LIR-STK there were selected sections of metallic profiled pipes.

Section of CFST members was selected by the methods of L.I. Storozhenko offered in the project of DSTU (National Standards of Ukraine) to DBN (Ukrainian National Construction Regulation) I.2.6 - 160 -2010 «Steel reinforced concrete structures».

Metal consumption was: columns $-9.1 \mathrm{t}$; one girder - $3.7 \mathrm{t}$; whole framing - $423 \mathrm{t}$. The consumption of monolithic concrete (grade V40) for filling in columns and compressed forms- $355 \mathrm{~m} 3$

\section{Conclusion}

1. Saving steel at the expense of : usage of concrete instead of steel in compression not only in columns and spandrel beams but in bracings; filling in with concrete and increasing of local strength of pipe walls, resistance increasing to local failures of thin-walled steel structures in assembling; three-dimensional operation of framing under horizontal stresses; absence of significant bending moments in columns causing eccentricity in joints as a result of pin-connected spandrel beams with columns; reduce of bending moment in spandrel beams at the expense of bracings which are like additional intermediary supports.

2. Reduction of labour intensity for assembling, construction terms due to: reduced cost of borrowed financial means at the expense of transferring a large number of operations connected with steel structure production from a construction site to a plant, i.e. metal structures production, partial filling in with concrete; unification of steel concrete spandrel beams and bracings independently on the location of members by the height of a building; assembling of prefabricated structures, reduced length of weld seams as the result of pinconnected joints and absence of stiff joints.

3.Reduction of size and cost of foundations at the expense of: reduction of total mass of steel concrete framing in comparison with reinforced concrete framing; absence of bending moment in supporting pin-connected joint of a column and foundation.

\section{References}

1. S.-H. Cai, Modern Street Tube Confined Concrete Structures (China Communication Press, Shanghai, 2003)

2. V. Mitrofanov, O. Dovzhenko, On the criterion of the limiting state for the strength of centrally 
compressed pipe-concrete elements. Utilities of cities, Economic sciences 63, 73-86 (2005)

3. A. Krishan, A. Zaikin, A. Melnichuk, Calculation of the strength of concrete columns. mechanics of engineering structures and structures 1, 20-25 (2010)

4. A. Kurochkin, Construction of frame buildings with load-bearing structures made of pipe-concrete elements. Vestnik MGSU 3, 82-86 (2010)

5. A. Etekbaeva, Strength and deformation of pipeconcrete compressed elements under alternating horizontal loads, Dissertation, 2010

6. I. Duvanova, I. Salmanov, Concrete columns in the construction of high-rise buildings and structures. Construction of unique buildings and structures $\mathbf{6}$, 89-103 (2014)

7. S. Ajmagambetova, High-rise construction taking into account the use of pipe-concrete structures, Dissertation, SPbGPU, 2013

8. S. Morino, K. Tsuba, Design and Construction of Concrete-Filled Steel Tube Column System in Japan. Earthquake and Engineering Seismology 4, 51-73 (2005)

9. P. Boyd, W. Cofer, D. McLean Seismic performance of steel-encased concrete columns under flexural loading. Journal of ACI 3, 353-364 (1995)

10. Y. Q. Tao, Z. Chen, Analysis and calculations of steel tube confined concrete (stcc) stub columns. Journal of Constructional Steel Research 66, 53-64 (2010)

11. F. Liu, H. Yang, Fe analysis of fire-resistance performance of concrete filled steel tubular columns under different loading cases. Harbin Gongye Daxue Xuebao 42, 201-204 (2010)

12. J. Qian, Z. Jiang, Experimental study on seismic behavior of steel tube-reinforced concrete composite shear walls with high axial compressive load ratio. Jianzhu Jiegou Xuebao 31, 40-48 (2010)

13. M. Garanzha, About approaches to the calculation of composite tubes in Ukraine and abroad. Metal constructions 20, 45-53 (2014)

14. Yu. Min, Zha. Xiaoxiong, Ye. Jianqiao, Li. Yuting, A unified formulation for circle and polygon concretefilled steel tube columns under axial compression. Engineering Structures, 49 (2013)

15. L. Storozhenko, Investigation of the Deformation State of a Composite Cable Space Frame Structures with a Photogrammetric Method. International Journal of Engineering \& Technology 7, 442-446 (2018). doi:10.14419/ijet.v7i3.2.14568

16. N. Savitsky, N. Kotov, Extending the scope of highstrength steel structures in residential and civil engineering. Metallurgical and Mining Industry 1, 113-116 (2014) 